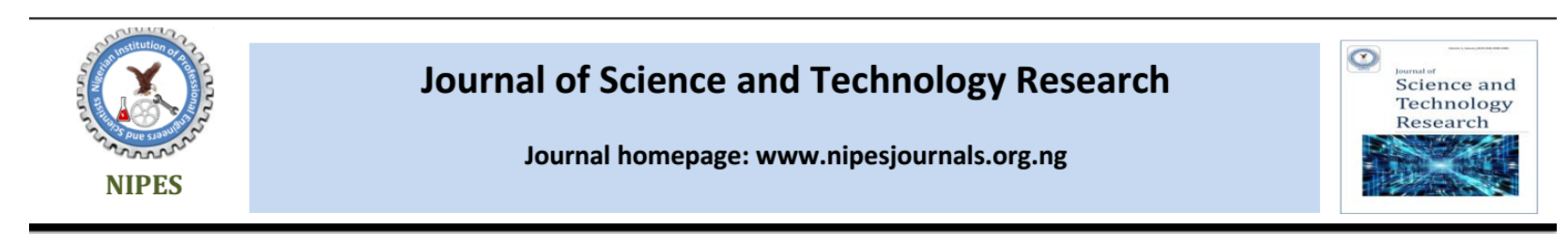

\title{
Measurement of Levels of Concentrations of Some Heavy Metals in Soils of Some Selected Areas of Pindiga, Nigeria
}

\author{
Muhammad Hassan ${ }^{a, b}$, Yakubu H. Ngadda ${ }^{b}$ and Aliyu Adamu ${ }^{b}$ \\ ${ }^{a}$ Centre for Nuclear Energy Research and Training (CNERT), University of Maiduguri, Nigeria \\ ${ }^{b}$ Department of Physics, University of Maiduguri, Nigeria
}

\section{Article Info}

\section{Keywords:}

Heavy Metals,

Level, Concentration,

Atomic Absorption Spectroscopy,

Mining, Pindiga

Received 26 February 2020

Revised 02 April 2020

Accepted 03 April 2020

Available online 1 June 2020

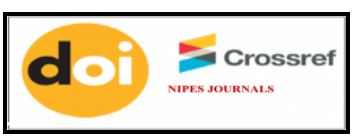

https://doi.org/10.37933/nipes/2.2.2020.4

https://nipesjournals.org.ng ISSN-2682-5821/@ 2020 NIPES Pub. All rights reserved.

\begin{abstract}
The population health risk due to heavy metal exposure has been becoming serious and worldwide environmental issue that has attracted considerable public attention. In this study, the level of heavy metal $(\mathrm{Cd}, \mathrm{Cr}, \mathrm{Fe}$, As and $\mathrm{Pb})$ in soil samples were determined using Atomic Absorption Spectrophotometer methods (AAS) to assess heavy metals contamination of soil due to mining activities around Gombe, Nigeria. The results obtained showed that the highest concentrations of $96.7271 \pm 2.770 \mathrm{mg} / \mathrm{kg}$ for Fe were observed in Unguwar Baka I, 25.5355 $\pm 1.782 \mathrm{mg} / \mathrm{kg}$ for $\mathrm{Pb}$ were observed in Unguwar Baka I, 21.9673 $\pm 2.047 \mathrm{mg} / \mathrm{kg}$ for $\mathrm{Cr}$ were observed in Tumu, 12.9675 1.969 for Cd were observed in Unguwar Baka I and $0.5782 \pm 0.025 \mathrm{mg} / \mathrm{kg}$ for As were observed in Unguwar Baka. In all the sampling locations, the levels of heavy metals in soil samples measured have the variation pattern in the order: $\mathrm{Fe}>\mathrm{Cr}>\mathrm{Pb}>\mathrm{Cd}$ $>$ As. The levels of the $\mathrm{Fe}, \mathrm{Cr}, \mathrm{Pb}, \mathrm{Cd}$, and As are higher than the World Health Organization (WHO) permissible limits in soil. This indicates that their concentration in the soil had the higher capability to pose severe health risk to the community of that area. This information will contribute to awareness of the potential impacts of heavy metals pollutants around the mining area of Gombe state.
\end{abstract}

\section{Introduction}

Heavy metals are elements with an atomic mass greater than 20, have metallic properties and density greater than $5 \mathrm{~g} / \mathrm{cm}^{3}[1,2]$. Non-biodegradable heavy metals like Nickel $(\mathrm{Ni})$, Chromium $(\mathrm{Cr})$, Cadmium $(C d)$, Mercury $(H g)$, Silver $(A u)$, Lead $(P b)$ and Arsenic $(A s)$ are highly toxic even at low concentrations [3-5]. Soil is composed of mineral constituents, organic matter, living organisms, air and water $[2,6,7]$. Heavy metals occur naturally in soils by geological processes, such as alteration and erosion of the geological underground materials [8,9]. Several researchers have subsequently shown that the accumulation of heavy metals and other chemical residues in the soils, water and air include mining, cement plant, fossil fuel, coal combustion chemical plants, smelting, waste disposal, urban effluent, vehicle exhausts, sewage sludge, pesticides and fertilizers application [10-20].

Mining of solid minerals have been identified as a source of heavy metal contamination of soil, water and air in Nigeria [21]. Heavy metal poses a great threat to the agriculture, environmental and public health due to their translocation and accumulation through food chains [7,20,22-24]. Heavy metal exposure to human occurs through three primary routes namely inhalation, ingestion and skin 
absorption. Contamination of soil with heavy metals is common and it can be a major source of metals to crops and finally may be a primary path of human exposure to these potentially toxic metals [25]. Moreover, heavy metals enter food chains from polluted soil, water and air, and consequently cause food contamination, thus posing a threat to human and animal health [1]. When heavy metals are transferred into food chains and accumulate in vital organs, such as the liver, kidneys, and bones, there is a direct threat to human health that can result in numerous serious health disorders [26].

The exposure to cadmium $(C d)$ and lead $(P b)$ is especially dangerous during prenatal development and infancy. Cadmium $(C d)$ causes skeletal disorders, liver damage, cardiovascular diseases, dysfunctions of the sexual glands, and disrupts a mineral balance in the body $[27,28]$. Chronic exposure of $C d$ can have harmful effects such as lung cancer, prostatic proliferative lesions, bone fractures, kidney dysfunction, and hypertension. The bioaccumulation of $P b$ in the human body interferes with proper functioning of the mitochondria thereby impairing respiration as well as causing constipation, swelling of the brain, paralysis and could eventually lead to death $[2,26,29]$. Lead $(P b)$ also causes cardiovascular diseases, kidney and liver dysfunctions and disorders of the immune and the reproductive systems [30]. High concentration of chromium $(\mathrm{Cr})$ can be responsible for non-carcinogenic health hazards such as neurological involvement, headache with liver disease. Human exposure to $C d$ above safe concentration limits is a recognized risk for the health [31]. High concentration iron $(\mathrm{Fe})$ in body tissues can lead to tissue damage [32]. Several studies have suggested that inorganic arsenic (As) affects DNA repair mechanisms and acts as a co- mutagen in bacterial test systems by inhibiting the repair of damage to DNA caused by another agent. Arsenic (As) poisoning with is dominated by changes in the skin and mucous membranes and by neurological, vascular and haematological lesions. Its Involvement of the gastrointestinal tract, increased salivation, irregular dyspepsia, abdominal cramps and loss of weight may also occur $[33,34]$. The population health risk due to heavy metal exposure has been becoming serious and worldwide environmental issue that has attracted considerable public attention particularly in the developing countries. Therefore heavy metal pollution is a global challenge that requires joint efforts of governments, scientists, and communities. Pindiga is a city found in Gombe, North-Eastern Nigeria having about 106,322 inhabitants. It is located $9.98^{\circ}$ North latitude, $10.93^{\circ}$ East longitude and it is situated at elevation $523 \mathrm{~m}$ above sea level [35].

In this study, the level of heavy metal $(C d, C r, F e, A s$ and $P b)$ in soil from mining area of Pindiga were determined using Atomic Absorption Spectrophotometer methods (AAS) to assess heavy metals contamination of soil due to mining activities around Gombe, Nigeria. This information will contribute to awareness of the potential impacts of heavy metals pollutants around the mining area.

\section{Methodology}

\subsection{Soil Sampling}

To measure level of heavy metals in Pindiga (were mining activities are prominent), soil samples each about $1.00 \mathrm{~kg}$ were collected at a depth of about $0-15 \mathrm{~cm}$ during the month of July (wet season). GPS (Global Positioning System) was used to record the exact position of the sampling sites. Containers for the samples were washed with solution of detergent and then rinsed with distilled water, freshly distilled hydrochloric acid $(\mathrm{HCl})$ to remove any inorganic material that might have stuck to the walls of the container before the samples were collected. Samples collected were put in a separate polythene bag to avoid cross contamination and then taken to the laboratory. Table 1 shows the sampling location sites with co-ordinates in the study area of water sampling. 
Muhammad Hassan et al./ NIPES Journal of Science and Technology Research

2(2) 2020 pp. 35-42

Table 1: Sampling location sites with co-ordinates in the study area (Pindiga, Akko LG) of soil sampling

\begin{tabular}{|c|c|c|}
\hline \multirow[t]{2}{*}{ Name of the Location } & \multicolumn{2}{|c|}{ Co-ordinates } \\
\hline & Latitude & Longitude \\
\hline Abbayo Quaters I & $9^{\circ} 59^{\prime} 0.79^{\prime \prime} N$ & $10^{\circ} 57^{\prime} 7.76^{\prime \prime} E$ \\
\hline Abbayo Quaters II & $9^{\circ} 59^{\prime} 0.98^{\prime \prime} N$ & $10^{\circ} 57^{\prime} 7.60 ” E$ \\
\hline Unguwar Baka & $9^{\circ} 59^{\prime} 7.63 ” N$ & $10^{\circ} 57^{\prime} 8.82 ” E$ \\
\hline Unguwar Baka I & $9^{\circ} 59^{\prime} 7.85^{\prime \prime} \mathrm{N}$ & $10^{\circ} 57^{\prime} 8.99 \prime \prime E$ \\
\hline Unguwar Baka II & $9^{\circ} 59^{\prime} 16.94 " N$ & $10^{\circ} 56^{\prime} 47.74 " E$ \\
\hline Tumu & $9^{\circ} 58^{\prime} 55.03 ” N$ & $11^{\circ} 8^{\prime} 53.32^{\prime \prime} E$ \\
\hline Piyau & $9^{\circ} 58^{\prime} 50.95 ” N$ & $11^{\circ} 8^{\prime} 58.89^{\prime \prime} E$ \\
\hline
\end{tabular}

\subsection{Equipment and Apparatus}

Apparatus such as volumetric flasks, measuring cylinder and digestion flasks were thoroughly washed with detergents and tap water and then rinsed with deionized water. All glass wares were cleaned with $10 \%$ concentrated Nitric acid $\left(\mathrm{HNO}_{3}\right)$ in order to clear out any heavy metal on their surfaces and then rinsed with distilled-deionised water. The digestion tubes were soaked with $1 \%$ (w/v) potassium dichromate in $98 \%(\mathrm{v} / \mathrm{v}) \mathrm{H}_{2} \mathrm{SO}_{4}$ and the volumetric flasks in $10 \%(\mathrm{v} / \mathrm{v}) \mathrm{HNO}_{3}$ for 24 hours followed by rinsing with deionized water and then dried in oven and kept in dust free place until analysis began. Prior to each use, the apparatus was soaked and rinsed in deionized water.

i. Analytical balance, 250-g capacity, resolution $0.0001 \mathrm{~g}$, OHAUS, PA214 pioneer USA

ii. Glass ware: Borosilicate volumetric flasks $(25 \mathrm{ml}, 50 \mathrm{ml}, 100 \mathrm{ml}$ and $1000 \mathrm{ml})$, Measuring cylinders,

iii. $\quad$ Micropipettes $(1-10 \mathrm{ml}, 100-1000 \mathrm{ml})$

iv. Atomic absorption spectrophotometer (Buck scientific model 210VGP AAS, USA; equipped with hollow cathode lamps and air-acetylene flame)

v. Microwave digester (Master 40 serial No: 40G106M)

\subsection{Sample Pre-Treatment/Digestion (solid samples)}

Reagents and chemicals used for the laboratory works were all analytical grade: Deionized water (chemically pure with conductivity $1.5 \mu \mathrm{s} / \mathrm{cm}$ and below was prepared in the laboratory) was used for dilution of sample and intermediate metal standard solutions prior to analysis and rinsing glassware and sample bottles. The samples were allowed to dry using hot oven (Model 30GC lab oven) and then ground into fine powder by using a porcelain mortar and pestle. About $200 \mathrm{mg}$ of each sample was weighed in to thoroughly clean plastic container (microwave tube), $6 \mathrm{ml}$ of $65 \%$ $\mathrm{HNO}_{3}$ and $2 \mathrm{ml}$ of $\mathrm{H}_{2} \mathrm{O}_{2}$ at ratio 3:1 was added and allowed to stand for a while. The plastic container (microwave tube) was then covered and placed in to microwave digester (Master 40 serial No: 40G106M) and digested.

The digestion was carried out at a temperature of $\left(120^{\circ} \mathrm{C}\right)$ for $10 \mathrm{~min}$ and then ramped at $10{ }^{\circ} \mathrm{C} \mathrm{min}^{-}$ ${ }^{1}$ to $180{ }^{\circ} \mathrm{C}$ and hold for $30 \mathrm{~min}$. The digestion was followed by a cooling to room temperature in the microwave. Potential presences of metal/elements in chemicals used in digestion were determined. Blanks were used simultaneously in each batch of the analysis to authenticate the analytical quality. The digested samples were diluted with deionized water to a total volume of 25 $m l$. 


\subsection{Preparation of $1000 \mathrm{mg} / \mathrm{kg}$ stock AAS standard solution for $\mathrm{Fe}, \mathrm{Pb}, \mathrm{Cd}, \mathrm{Cr}$ and $\mathrm{As}$}

The determination of a given metal concentration in the experimental solution was based on its respective calibration curve. In plotting the calibration curves for lead, cadmium, zinc, chromium and arsenic, a stock solution of each metal ion of (1000 ppm) supplied by manufacturers company was used, from which a standard working solution of $100 \mathrm{ppm}$ was prepared.

Standard working solution: $100 \mathrm{ppm}$ was prepared as working solution from the $1000 \mathrm{ppm}$ already prepared. A simple dilution formula $\left(C_{1} V_{1}=C_{2} V_{2}\right)$ was used to calculate the volume of the stock solution to be diluted to the new desired concentration. $1 \mathrm{~mL}$ of concentrated $\mathrm{HNO}_{3}$ was added to each working standard and finally diluted to the desired volume with deionised water. To prepare $100 \mathrm{ppm}, 10 \mathrm{ml}$ of the standards and other stock solutions were pipetted and added in to $100 \mathrm{ml}$ calibrated flasks finally diluted with deionized water and the solution was mixed thoroughly. The other standard working solutions were prepared from $100 \mathrm{ppm}$ by pipetting out appropriate volume in to calibrated flasks and made up to volume with deionized water.

\subsection{Determination of metal content by AAS}

Calibration curves were prepared to determine the concentration of the metals in the sample solution. The instrument was calibrated using series of working standards. The working standard solutions of each metal were prepared from standard solutions of their respective metals and their absorbances were taken using the AAS. Calibration curve for each metal ion to be analyzed was prepared by plotting the absorbance as a function of metal ion standard concentration. Concentration of the metal ions present in the sample was determined by reading their absorbance using AAS (Buck scientific model 210GP) and comparing it on the respective standard calibration curve. Three replicate determinations were carried out on each sample. The metals were determined by absorption/concentration mode and the instrument readout was recorded for each solution manually. The same analytical procedure was employed for the determination of elements in digested blank solutions and for the spiked samples.

Data was analyzed using Microsoft Office Excel. Means and standard deviations (Mean \pm SD) were used to assess the contamination levels of heavy metals in soil samples.

\section{Results and Discussion}

The concentrations of heavy metals $(\mathrm{Fe}, \mathrm{Pb}, \mathrm{Cr}, \mathrm{Cd}, \mathrm{As})$ in soil collected from seven different samples source (Abbayo Quarters I, Abbayo Quarters II, Unguwar Baka, Unguwar Baka I, Unguwar Baka II, Tumu and Piyau) were determined using atomic absorption spectroscopy (AAS) and the results obtained were presented in Table 2. The mean concentrations range from $12.1672 \pm 1.052$ to $96.7271 \pm 2.770 \mathrm{mg} / \mathrm{kg}$ for iron, $4.8019 \pm 1.543$ to $25.5355 \pm 1.782 \mathrm{mg} / \mathrm{kg}$ for $\mathrm{Pb}, 9.9707 \pm 4.622$ to $21.9673 \pm 2.047 \mathrm{mg} / \mathrm{kg}$ for $\mathrm{Cr}$, and ND to $12.9675 \pm 1.969 \mathrm{mg} / \mathrm{kg}$ for $C d$ and $0.0487 \pm 0.027$ to $0.5782 \pm 0.025 \mathrm{mg} / \mathrm{kg}$ for $\mathrm{As}$. The highest concentrations of $96.7271 \pm 2.770 \mathrm{mg} / \mathrm{kg}$ for $\mathrm{Fe}$ were observed in Unguwar Baka I, while the least value of $12.1672 \pm 1.052 \mathrm{mg} / \mathrm{kg}$ was observed in Piyau. The highest concentrations of $25.5355 \pm 1.782 \mathrm{mg} / \mathrm{kg}$ for $P b$ were observed in Unguwar Baka I, while the least value of $4.8019 \pm 1.543 \mathrm{mg} / \mathrm{kg}$ was observed in Unguwar Baka II. The highest concentrations of $21.9673 \pm 2.047 \mathrm{mg} / \mathrm{kg}$ for $\mathrm{Cr}$ were observed in Tumu, while the least value of $8.56783 \pm 1.768 \mathrm{mg} / \mathrm{kg}$ was observed in Abbayo Quarters I. The highest concentrations of 12.9675 \pm 1.969 for $C d$ were observed in Unguwar Baka I, while $C d$ was not detected in Unguwar Baka, Unguwar Baka II, Tumu and Piyau. The highest concentrations of $0.5782 \pm 0.025 \mathrm{mg} / \mathrm{kg}$ for As were observed in Unguwar Baka, while the least value of $0.0487 \pm 0.027 \mathrm{mg} / \mathrm{kg}$ was observed in Unguwar Baka II. 
Muhammad Hassan et al./ NIPES Journal of Science and Technology Research

2(2) 2020 pp. 35-42

Table 2: Mean Concentrations of Some Heavy Metals in Soil Samples from seven locations

\begin{tabular}{|c|c|c|c|c|c|}
\hline \multirow{2}{*}{$\begin{array}{c}\text { Name of the } \\
\text { Location }\end{array}$} & \multicolumn{5}{|c|}{ Concentration $(m g / k g)$ Mean \pm SD } \\
\hline & Iron & Lead & Chromium & Cadmium & Arsenic \\
\hline Abbayo Quaters I & $82.5854 \pm 2.116$ & $16.4409 \pm 1.3609$ & $8.56783 \pm 1.768$ & $2.01094 \pm 1.786$ & $0.4807 \pm 0.043$ \\
\hline Abbayo Quaters II & $91.0693 \pm 4.233$ & $21.8983 \pm 2.722$ & $15.1613 \pm 2.804$ & $8.9497 \pm 3.006$ & $0.4929 \pm 0.430$ \\
\hline Unguwar Baka & $64.4842 \pm 2.399$ & $4.8019 \pm 1.543$ & $9.9707 \pm 4.622$ & ND & $0.5782 \pm 0.025$ \\
\hline Unguwar Baka I & $96.7271 \pm 2.770$ & $25.5355 \pm 1.782$ & $18.9083 \pm 1.836$ & $12.9675 \pm 1.969$ & $0.0487 \pm 0.027$ \\
\hline Unguwar Baka II & $18.9529 \pm 5.806$ & $4.5324 \pm 1.2824$ & $17.1181 \pm 4.529$ & ND & $0.1002 \pm 0.019$ \\
\hline Tumu & $25.1686 \pm 2.624$ & $10.8767 \pm 2.221$ & $21.9673 \pm 2.047$ & ND & $0.0636 \pm 0.009$ \\
\hline Piyau & $12.1672 \pm 1.052$ & $8.1575 \pm 0$ & $19.9415 \pm 5.127$ & ND & $0.1110 \pm 0.012$ \\
\hline Mean & 41.2646 & 9.7311 & 11.7767 & 2.5243 & 0.1978 \\
\hline
\end{tabular}

Figure 1 shows the bar chart representation of the concentration of iron $(\mathrm{Fe})$, lead $(\mathrm{Pb})$, chromium $(C r)$ cadmium $(C d)$ and arsenic $(A s)$ in soil samples from four locations.

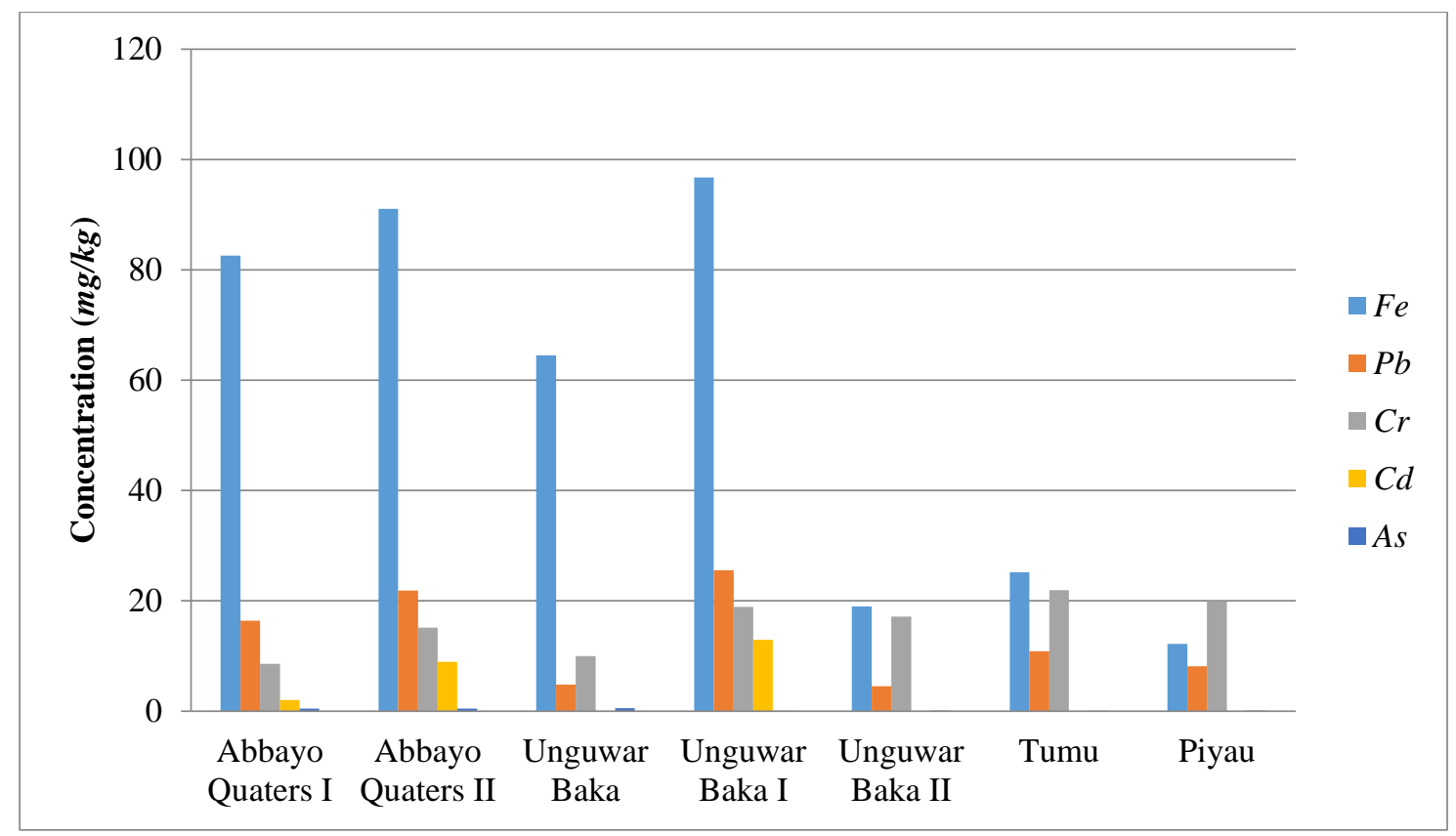

Figure 1: The concentration of iron $(F e)$, lead $(P b)$, chromium $(C r)$, cadmium $(C d)$ and arsenic $(A s)$ in soil samples from seven locations.

Figure 1 shows the concentration of iron $(\mathrm{Fe})$, lead $(\mathrm{Pb})$, chromium $(\mathrm{Cr})$, cadmium $(\mathrm{Cd})$ and arsenic $(A s)$ in soil samples taken from Abbayo Quaters I, Abbayo Quaters II, Unguwar Baka, Unguwar Baka I, Unguwar Baka II, Tumu and Piyau. The values of all the heavy metals analyzed in soil samples from Unguwar Baka I and Unguwar Baka II are relatively higher than those from other locations and Piyau has the lowest concentration of heavy metals. 
Muhammad Hassan et al./ NIPES Journal of Science and Technology Research 2(2) 2020 pp. $35-42$

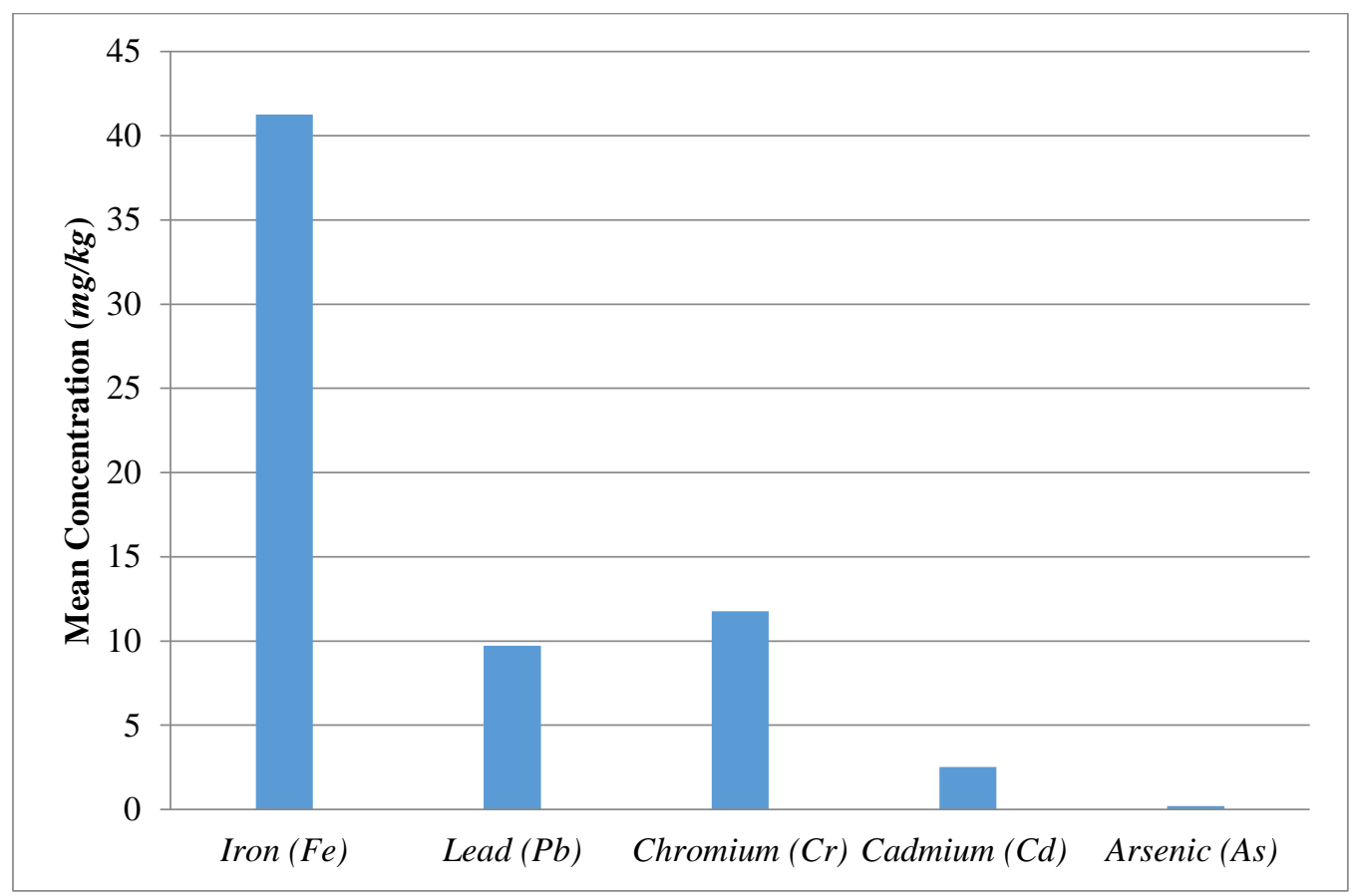

Figure 2: The mean concentration of iron $(\mathrm{Fe})$, lead $(\mathrm{Pb})$, chromium $(\mathrm{Cr})$, cadmium $(\mathrm{Cd})$ and arsenic $(\mathrm{As})$ in the study area

Figure 2 shows the mean concentration of $\mathrm{Fe}$ (41.2646 $\mathrm{mg} / \mathrm{kg}), \mathrm{Pb}(9.7311 \mathrm{mg} / \mathrm{kg}), \mathrm{Cr}(11.7767$ $\mathrm{mg} / \mathrm{kg}), C d(2.5243 \mathrm{mg} / \mathrm{kg})$ and $A s(0.1978 \mathrm{mg} / \mathrm{kg})$ in soil samples from the study area. It can be seen from Figure 3 that $\mathrm{Fe}$ has the highest mean concentration of $41.2646 \mathrm{mg} / \mathrm{kg}$ followed by $\mathrm{Cr}(11.7767$ $\mathrm{mg} / \mathrm{kg}), \mathrm{Pb}(9.7311 \mathrm{mg} / \mathrm{kg})$ and $C d(2.5243 \mathrm{mg} / \mathrm{kg})$. Arsenic $(A s)$ has the lowest mean value concentration of $0.1978 \mathrm{mg} / \mathrm{kg}$. Therefore, the levels of heavy metals in soil samples measured in this study have the variation pattern in the order: $\mathrm{Fe}>\mathrm{Cr}>\mathrm{Pb}>\mathrm{Cd}>\mathrm{As}$. The mean concentration of $P b(9.7311 \mathrm{mg} / \mathrm{kg})$ in the soil samples from the study area was found to be above the WHO standard maxima of $0.01 \mathrm{mg} / \mathrm{kg}$ and the values are below the tolerable levels of $90-300 \mathrm{mg} / \mathrm{kg}$ [4]. This value indicates no risk to environment in terms of $P b$ concentration. The mean concentration of $C d(2.5243 \mathrm{mg} / \mathrm{kg})$ is beyond the WHO (2008) permissible limit and could post a thread of the toxicity of heavy metals [36]. According to WHO (2008), the maximum limit for $C d$ is $0.35 \mathrm{mg} / \mathrm{kg}$ [21]. The exposure to heavy metals has serious health implication such as dysfunctions of the sexual glands, disrupts mineral balance in the body lung cancer, paralysis, cardiovascular diseases, kidney dysfunction, liver damage, disorders of the immune and the reproductive systems, and is dangerous during prenatal development and infancy.

\section{Conclusion}

In all the sampling locations, the levels of heavy metals in soil samples measured in this study have the variation pattern in the order: $\mathrm{Fe}>\mathrm{Cr}>\mathrm{Pb}>\mathrm{Cd}>\mathrm{As}$. Iron $(\mathrm{Fe})$ has the highest mean concentration of $41.2646 \mathrm{mg} / \mathrm{kg}$ and it is beyond the permissible limit. The mean concentration of $\mathrm{Pb}(9.7311 \mathrm{mg} / \mathrm{kg})$ in the soil samples from the study area was found to be above the WHO standard maxima of $0.01 \mathrm{mg} / \mathrm{kg}$ and the values are below the tolerable levels of $90-300 \mathrm{mg} / \mathrm{kg}$. This value indicates no risk to environment in terms of $\mathrm{Pb}$ concentration. The mean concentration of $C d$ $(2.5243 \mathrm{mg} / \mathrm{kg})$ is beyond the permissible limit and could post a thread of the toxicity of heavy metals. The maximum limit for $C d$ is $0.35 \mathrm{mg} / \mathrm{kg}$. This study showed the mean concentration of $\mathrm{Fe}$, $\mathrm{Pb}$ and $\mathrm{Cr}$ in soil samples is relatively high and is beyond the permissible limit set by WHO (2008). 
Muhammad Hassan et al./ NIPES Journal of Science and Technology Research

2(2) 2020 pp. 35-42

The high concentration of $\mathrm{Fe}(41.2646 \mathrm{mg} / \mathrm{kg}), \mathrm{Pb}(9.7311 \mathrm{mg} / \mathrm{kg})$ and $\mathrm{Cr}(11.7767 \mathrm{mg} / \mathrm{kg})$ detected in soil samples can be attributed to mining activities that is taking place in the study area (Pindiga).

Since the concentrations of these heavy metals are greater than the recommended standards, it is therefore suggested that:

$i$. There is need to further study the concentrations of such heavy metals in plants and vegetables grown in that area, animals that fed on the plants and any other source that directly or indirectly link to the source of food of the populace.

ii. Regular monitoring of levels of heavy metal in soil of Pindiga is encouraged to ensure suitable management of the urban environment.

iii. The people in Pindiga community should be educated on health risk associated with human exposure to heavy metals to prevent further pollution.

\section{Acknowledgement}

The authors would like to thank the Nigerian Atomic Energy Commission, NAEC for their funding through Centre for Nuclear Energy Research and Technology, University of Maiduguri Nigeria. The authors are grateful to N-CERT Zaria and CNERT Maiduguri staffs, especially Lawan Dauda, Fa'iza M. Bello for their support in this work. The cooperation received from emir of Pindiga, HRH. Alh. Muhammad S. Ahmad and Muhammad I. Ahmad during field measurements is gratefully acknowledged.

\section{References}

[1] He, Z., Shentu, J., Yang, X., Baligar, V.C., Zhang, T. and Stoffella, P. J. (2015). Heavy Metal Contamination of Soils: Sources, Indicators, and Assessment, Journal of Environmental Indicators, Volume 9 page 17 - 18.

[2] Addis, W. and Abebaw, A. (2017). Determination of heavy metal concentration in soils used for cultivation of Allium sativum L. (garlic) in East Gojjam Zone, Amhara Region, Ethiopia, Wodaje Addis and Alemayehu Abebaw, Cogent Chemistry, Volume 3, Number 1419422.

[3] Osmani, M., Bani, A. and Hoxha, B. (2015). Heavy Metals and Ni Phytoextractionin in the Metallurgical Area Soils in Elbasan, Albanian j. agric. Science, Volume 14 Number 4, page $414-419$.

[4] Opaluwa, O. D., Aremu, M. O., Ogbo, L. O, Abiola, K. A., Odiba, I. E., Abubakar, M. M. and Nweze, N. O. (2012). Heavy metal concentrations in soils, plant leaves and crops grown around dump sites in Lafia Metropolis, Nasarawa State, Nigeria. Advances in Applied Science Research, Volume 3, Number 2, page 780 - 784.

[5] USEPA, (2001). Supplemental Guidance for Developing Soil Screening Levels for Superfund Sites. Peer Review Draft, Washington, DC. US Environmental Protection Agency Office of Solid Waste and Emergency Response, OSWER, page $9355-9364$.

[6] Amshi, S. A., Adamu, A., Yesufu, H. and Milagawanda, H. (2019). Health Risk Assessment of some Heavy Metals (Cd, Pb, Cr) in Soil Sample from Gashua, Yobe, Nigeria, Journal of Science and Technology Research, Volume 1, Number 2, page $136-143$.

[7] Ekmekyapar, F., Şabudak, T. and Şeren, G. (2012). Assessment of Heavy Metal Contamination in Soil and Wheat (Triticum Aestivum L.) Plant around the Çorlu-Çerkezkoy Highway in Thrace Region, Global NEST Journal, Volume 14, Number 4, page $496-504$.

[8] Moor, C., Lymberopoulou, T., Dietrich, V. K. (2001). Determination of Heavy Metals in Soils, Sediments and Geological Materials by ICP- AES and ICP-MS. Mikrochim. Acta. Volume 136, page $123-128$.

[9] Kabir, E., Ray, S., Kim, K. H., Yoon, H. O., Jeon, E. H., Kim, Y. S., Cho, Y. S., Yun, S. T., Brown, R. J. C. (2012). Current Status of Trace Metal Pollution in Soils Affected by Industrial Activities. Sci. World J., page $1-18$.

[10] Rao, P. S., Thomas, T. A. and David, A. (2017). Determination of Heavy Metals Contamination in Soil and Vegetable Samples from Jagdalpur, Chhattisgarh State, India. International Journal of Current Microbiology and Applied Sciences, Volume 6, Number 8, page 2909-2914.

[11] Ukpong, E. C., Antigha, R. E., Moses, E. O. (2013). Assessment of Heavy Metals Content in Soils and Plants around Waste Dumpsites in Uyo Metropolis, Akwa Ibom State. The IJES. Volume 2, Number 7, page $75-86$.

[12] Reuss, J., Dooley, H. L., and Griffis, W. (1976). Plant uptake of cadmium from phosphate fertilizers. Ecological Research Service, page $1-37$.

[13] Ayuso, M., Hernández, T., García, C., and Pascual, J. A. (1996). Biochemical and chemical-structural characterization of different organic materials used as manures. Bioresource Technology, Volume 57, page $201-207$.

[14] Mortvedt, J. J. (1996). Heavy metal contaminants in inorganic and organic fertilizers. Fertilizer Research, Volume 43, page $55-61$. 
[15] Ihnat, M., and Fernandes, L. (1996). Trace element characterization of composted poultry manure. Bioresource Technology, Volume 57, page $143-156$.

[16] Haroun, M., Idri, A., and Omar, S. (2009). Analysis of heavy metals during composting of the tannery sludge using physicochemical and spectroscopic techniques. Journal of Hazardous Materials, Volume 165, page $111-119$.

[17] Worthington, V. (2001). Nutritional quality of organic vs. conventional fruits, vegetables and grains. Journal of Alternative and Complementary Medicine, Volume 7, page $161-175$.

[18] Arora M, Kiran B, Rani S, Rani, A, Kaur B, and Mittal N. (2018). Heavy metal accumulation in vegetables irrigated with water from different sources. Food Chemistry, Volume 111, page $811-815$.

[19] Dikwa, M. K., Akan, J. C. and Adamu, A. (2019). Determination of Some Heavy Metals in Roadside Soils from Some Major Roads in Maiduguri, Borno State, Nigeria. Nuclear Science, Volume 4, Number 3, page 27 - 33.

[20] Ripin, S. M., Hasan, S., Kamal, M. L. and Hashim, N. M. (2014). Analysis and Pollution Assessment of Heavy Metal in Soil, Perlis. The Malaysian Journal of Analytical Sciences, Volume 18, Number 1, page $155-161$.

[21] Sanusi, K. A., Hassan, M. S., Abbas, M. A. and Kura, A. M. (2017). Assessment of heavy metals contamination of soil and water around abandoned $\mathrm{Pb}-\mathrm{Zn}$ mines in Yelu, Alkaleri Local Government Area of Bauchi State, Nigeria. International Research Journal of Public and Environmental Health, Volume 4, Number, 5, page $72-77$.

[22] Zhiyuan, Q. Y., Lua, L. X., Lei, Q. D. and Bia, H. J. (2018). A review of soil heavy metal pollution from industrial and agricultural regions in China: Pollution and risk assessment. The Total Environment, Volume 642, page $690-700$.

[23] Li, C., Zhou, K., Qin, K., Tian, C., Qi, M., Yan, X. and Han, W. (2019). A Review on Heavy Metals Contamination in Soil: Effects, Sources, and Remediation Techniques, Soil and Sediment Contamination: An International Journal, Volume 28, Number 4, page $380-394$.

[24] Proshad, R., Islam, M. S., Kormoker, T., Bhuyan, M. S., Hanif, M. A., Hossain, N. (2019). Contamination of Heavy Metals in Agricultural Soils: Ecological and Health Risk Assessment. Science Forecast Journal of Nanochem Nanotechnology, Volume 2, Number 1, page 1012.

[25] Maleki, A., Gharibi, F., Alimohammadi, M., Daraei, H. and Zandsalimi, Y. (2014). Concentration levels of heavy metals in irrigation water and vegetables grown in periurban areas of Sanandaj, Iran. J Adv Environ Health Res, Volume 1, Number 2, page $81-88$.

[26] Hu, B., Jia, X., Hu, J., Xu, D., Xia, F. and Li, Y. (2017). Assessment of Heavy Metal Pollution and Health Risks in the SoilPlant-Human System in the Yangtze River Delta, China. International Journal of Environmental Research and Public Health, Volume 14, page 1042.

[27] Amshi, S. A., Iliya, I. and Adamu, A. (2019). Chronic Kidney Disease Associated With Heavy Metals (Cr, Pb, Cd) Analyzed From Irrigation Water of Gashua, Yobe, Nigeria. IOSR Journal of Applied Chemistry (IOSR-JAC). Volume 12, Issue 5 Ser. I, page $53-58$.

[28] Wu, H., Liao, Q., Chillrud, S. N., Yang, Q. Huang, L. Bi, J. and Yan, B. (2016). Environmental Exposure to Cadmium: Health Risk Assessment and its Associations with Hypertension and Impaired Kidney Function. Sci. Rep., Volume 6, 29989.

[29] Shah, F., Niaz, A., Ullah, N., Rehman, A., Akhlaq, M., Zakir, M. and Khan, M. S. (2013). Comparative Study of Heavy Metals in Soil and Selected Medicinal Plants. Hindawi Publishing Corporation Journal of Chemistry Volume 2013, Article ID 621265, 5pages.

[30] Zwolak, A., Sarzyńska, M., Szpyrka, E. and Stawarczyk, K. (2019). Sources of Soil Pollution by Heavy Metals and Their Accumulation in Vegetables: a Review. Water Air Soil Pollut., Volume 230, page 164.

[31] Achmad, R. T., Budiawan, B. and Auerkari, E. I. (2017). Effects of Chromium on Human Body. Annual Research and Review in Biology, Volume 13, Number 2, page $1-8$.

[32] Abbaspour, N., Hurrell, R., Kelishadi, R. (2014). Review on iron and its importance for human health. Journal of Research in Medical Sciences, Volume 19, page $164-74$.

[33] Lagerkvist, B. J. and Zetterlund, B. (1994). Assessment of exposure to arsenic among smelter workers: A five- year follow up. American journal of industrial medicine, Volume 25, page $477-488$.

[34] WHO, (2000). Arsenic Air Quality Guidelines Second Edition. WHO Regional Office for Europe, Copenhagen, World Health Organizations, Denmark, 2000.

[35] Abbati, M. A., Umar, D. M., Shuaibu, F. A., Ibrahim, U. G. and Ahmadu, A. U. (2019). Abundance and Distribution of Zooplankton in Pindiga Lake, Gombe State, Nigeria. Greener Journal of Biological Sciences, Volume 9, Number, 2 , page 35 $-42$.

[36] WHO, (2008). Guidelines for drinking - water Quality $3^{\text {rd }}$ Edition incorporating the first and second agenda, Volume 1, Recommendations, World Health Organizations, Geneva. 